\begin{tabular}{|c|c|c|}
\hline $\begin{array}{l}\text { KULTURA } \\
\text { I } \\
\text { SPOLECZENS }\end{array}$ & $\begin{array}{l}\text { POLSKA AKADEMIA NAUK } \\
\text { KOMITET SOCJOLOGII } \\
\text { INSTYTUT STUDIÓW POLITYCZNYCH } \\
2015, \mathrm{nr} 4\end{array}$ & ISSN 0023-5172 \\
\hline
\end{tabular}

IRENA PAŃKÓW

Instytut Studiów Politycznych PAN

\title{
ELITY ADMINISTRACYJNE. MISJA I ODPOWIEDZIALNOŚĆ
}

Podejmę tu próbę odpowiedzi na pytanie, czy i na jakich podstawach we współczesnej Polsce kształtuje się samoświadoma i (względnie) autonomiczna elita administracyjna. O autonomii elity, a więc także elity administracyjnej, decydują zasoby będące w jej posiadaniu. Przedmiotem mojej uwagi są głównie zasoby symboliczne, odtwarzane $z$ dwóch fragmentów narracji:

— ogólnej narracji o polityce i relacjach na linii polityka-administracja, urzędnicy-politycy;

- narracji o misji/odpowiedzialności/zadaniach.

Podstawę empiryczną opisu i analizy stanowią wywiady pogłębione $z$ dyrektorami i wicedyrektorami departamentów ${ }^{1}$. Analizy prowadzone są $\mathrm{w}$ perspektywie elitystycznej. Wybrane pojęcia teorii elit łączę z odpowiednimi tezami koncepcji Maksa Webera. Korzystam z pojęć i kategorii Weberowskich, takich jak polityka, biurokracja, odpowiedzialność, legitymizacja. Naturalnym zapleczem w próbach rozumienia badanych zjawisk jest współczesna psychologia społeczna. Autoprezentacja respondentów podlega prawidłowościom psychologicznym; wzmacnia ich autoafirmację i autolegitymizację.

Adres do korespondencji: ipank@isppan.waw.pl

${ }^{1}$ Materiał empiryczny poddany analizie został zgromadzony w trakcie badania zrealizowanego w ramach grantu Narodowego Centrum Nauki pt. „Elity administracyjne i polityczne państwa: kariery, tożsamości, relacje" (nr 2011/03/B/HS5/00825). W 2013 roku przeprowadzono wywiady swobodne z 50 dyrektorami ministerialnych departamentów (lub ich zastępcami). Zostały one nagrane, zapisane, a następnie ich treść poddano pogłębionym analizom jakościowym. Departamenty były losowane z listy wszystkich departamentów merytorycznych wszystkich resortów, z wyjątkiem Ministerstwa Gospodarki, którego władze nie wyraziły zgody na wywiady ze swoimi pracownikami. 
Zależy mi zatem, po pierwsze, na odtworzeniu schematów myślenia członków badanej zbiorowości o niej samej: postrzegania własnej roli, jej specyfiki, oczekiwań społecznych i politycznych oraz usytuowania $\mathrm{w}$ obszarze polityki. Po drugie $-z$ konfiguracji tych schematów chcę odczytać zarys formuł legitymizacyjnych należących do zasobu symbolicznego członków elit administracyjnych.

Interesuje mnie ten obszar zjawisk, które Czesław Znamierowski (1991), badacz elit z okresu międzywojennego, nazwał „samopoczuciem elit”. Wgląd $\mathrm{w}$ to, co myślą członkowie elit administracyjnych o sobie, ich ogólne samopoczucie, ma nas przybliżyć do odpowiedzi na ogólniejsze pytanie, czy i na jakich podstawach kształtuje się w Polsce samoświadoma elita administracyjna. Czy w badanej zbiorowości można dostrzec kreowanie „formuły legitymizacyjnej" specyficznej dla tego segmentu elity rządzącej — wyrażającej się we wspólnych treściach świadomości, podobnych schematach postrzegania rzeczywistości, schematach autopercepcji i autoafirmacji — oraz sposoby posługiwania się tą formułą.

\section{POLITYKA I ADMINISTRACJA: \\ PODPORZĄDKOWANIE, AUTONOMIA CZY WSPÓŁZALEŻNOŚĆ}

Elity administracyjne funkcjonują $\mathrm{w}$ porządku instytucjonalnym państwa i polityki, stanowią element funkcjonowania państwa oraz składnik szerszego procesu kształtowania się społeczeństwa (Weber 1998; Hausner 2008; Oszlak 2005; Wołek 2012). Są segmentem elity rządzącej, a ich usytuowanie wobec elit politycznych, modelowo ujmując, zawiera się między biegunami podporządkowania i autonomii. Zadaniem całej elity rządzącej we współczesnym społeczeństwie jest rozwiązywanie problemów społecznych, czyli realizowanie polityk publicznych, elicie administracyjnej zaś przypisana jest głównie implementacja owych polityk (Oszlak 2005; Zybała 2012).

Pomijam tu (skądinąd ważna) dyskusję teoretyczną dotyczącą stosowanych terminów: „elita”, „elita polityczna”, „elita rządząca” i pokrewnych ${ }^{2}$. Przyjmuję definicję instytucjonalną. Do elity należą osoby, które dzięki zajmowaniu pozycji strategicznej są „zdolne do kształtowania w istotny i systematyczny sposób polityki kraju" (Field, Higley, Burton 1990, s. 152). Eva Etzioni-Halevy (1998, s. 115) definiuje elitę jako grupę ludzi dysponujących władzą poprzez kontrolę różnorodnych zasobów. Przez zasoby symboliczne rozumie „wiedzę, informację czy możliwości takiego zestawiania symboli, aby dla innych lu-

\footnotetext{
2 Termin „elita rządząca” wprowadził do nauki Vilfredo Pareto (1994). Używa go wielu badaczy. Na przykład Jacek Raciborski (2006, s. 10), badając elitę rządową, również posługuje się terminem „elita rządząca”, jako kategorią szerszą od elity rządowej; elitę polityczną traktuje jako najszerszą grupę $\mathrm{w}$ zaproponowanym schemacie.
} 
dzi stawały się rzeczywistością”, do zasobów zalicza też „czynniki psychiczne i osobowościowe: charyzmę, czas, motywację czy pasję". Włodzimierz Wesołowski (1992, s. 29) w studium teoretyczno-empirycznym na temat polskich elit następująco odczytuje koncepcję Maksa Webera: „Wydaje się, że zgodne $z$ intuicjami Webera będzie takie zdefiniowanie elity politycznej, które odwoła się do jej roli lub «funkcji» w wyodrębnionej sferze życia społecznego, nazwanej sferą państwowo-polityczną. Decyzje państwowe - to główne zainteresowania tak zdefiniowanej elity" (podkr. - I.P.).

Dyrektorzy i wicedyrektorzy departamentów jako urzędnicy państwowi wysokiego szczebla podejmują istotne decyzje państwowe. Ważną kwestią uwzględnianą w teoriach elit i teoriach biurokracji oraz doświadczaną w codziennej praktyce członków elit administracyjnych jest ich udział (miejsce) w systemie politycznym, w podejmowaniu kluczowych decyzji oraz relacje polityka-administrowanie i politycy-urzędnicy. Współczesne teorie biurokracji zwracają uwagę na władzę biurokracji jako aktora w procesie decyzyjnym oraz na rosnącą pozycję urzędników państwowych, co prowadzi wręcz do „rządów urzędników" (Heywood 2006, s. 439). Podobną diagnozę, obudowaną wprawdzie wieloma pytaniami, sformułował dla czasów jemu współczesnych Max Weber (1998), według którego, „rzeczywiste panowanie” sprawują urzędnicy. Współczesne koncepcje demokratycznego elityzmu (a wcześniej Max Weber i Karl Mannheim) kładą nacisk na fakt współistnienia wielu współpracujących, wzajemnie kontrolujących się i autonomicznych elit (Etzioni-Halevy 1998; Peffley, Rohrschneider 2007). Czynnikiem formowania się elity jako bytu (względnie) autonomicznego i wskaźnikiem empirycznym tego procesu jest właśnie wymiar legitymizacyjny. Teoretycznie ujmując, formuła legitymizacyjna powinna $z$ jednej strony odzwierciedlać interesy i charakter elity, $z$ drugiej zaś - rolę polityczną i oczekiwania społeczne ${ }^{3}$. Szersze procesy modernizacji, jakim podlega Polska, a także realny, skomplikowany i zarazem zmienny splot elity administracyjnej z elitą polityczną wpływają na kształt zabiegów autolegitymizacji w tej zbiorowości oraz na świadomość społeczną respondentów. Przeobrażenia kulturowo-cywilizacyjne składające się na proces modernizacji (biurokracja jest nieodłączna od nowoczesności) w Polsce przypominają zjawiska, które w swoim czasie opisał Max Weber ${ }^{4}$, który przeprowadził przenikliwą analizę polityki i biurokracji na szerokim tle przemian społecznych. Interesowały go czynniki prowadzące do uformowania się nowoczesnego zachodniego

\footnotetext{
${ }^{3}$ Klasyk elityzmu, Gaetano Mosca, wydobywał takie cechy elity jak samoświadomość, spójność, sekretność (zob. Pańków 2008). Są one przesłanką do tworzenia się esprit de corps elity, także elity administracyjnej. Jak pokazują Ewa Nalewajko i Barbara Post (2014), wyobrażenia dyrektorów departamentów na temat dobrego państwa, dobrego urzędnika, etosu służby cywilnej są w badanej grupie „nieuzgodnione” i stosunkowo słabo zarysowane.

${ }_{4}^{4}$ Zdzisław Krasnodębski w Przedmowie do dzieła Webera Polityka jako zawód i powołanie (1998, s. 11) podkreśla trafność sformułowanej przez niego diagnozy: „dzisiaj pod pewnymi względami bliżej jesteśmy czasów Webera".
} 
społeczeństwa, biurokratyzacja była jednym z historycznych nośników nowoczesnego porządku ${ }^{5}$.

Główne trendy cywilizacyjne, jakim podlegał ówczesny świat, współtworzyły zjawisko, które Weber nazwał „odczarowywaniem świata”. Według jego diagnozy techniczna racjonalność przenika wszystkie sfery — logiki działania wypracowywane w świecie biurokracji ogarniają całe życie społeczne, gospodarkę i politykę (Weber 1998, s. 61). W czasach Webera to biurokracja i jej normy miały wyrażać „ducha czasów”. Ważnym zjawiskiem w obrębie tego trendu modernizacyjnego była autonomizacja poszczególnych elit i ich segmentów, a także sfer działania, $\mathrm{w}$ tym polityki i biurokracji.

Polityka, utrzymywał Weber, jest sferą szczególnego rodzaju odpowiedzialności, w której działania są nacechowane dylematami i sprzecznościami. Wynikają one między innymi ze związku z przemocą i, głębiej, z naturą świata, jego niekoherencją etyczną i irracjonalnością (dobro może wynikać ze zła, a zło może wynikać $z$ dobra). Biurokracja, a więc i podlegająca jej logice elita administracyjna, może stanowić przeciwwagę dla polityki - jako ostoja racjonalności, obiektywizmu, kompetencji. W Weberowskiej koncepcji biurokracja i urzędnicy są rzecznikami działań racjonalnych, nosicielami procesu „odczarowywania świata" . Takie usytuowanie może prowadzić do zmiany układu władzy: „W nowoczesnym państwie - pisał Weber - rzeczywiste pa n ow a ni e, które nie polega na przemówieniach parlamentarnych ani na enuncjacjach monarchów, lecz na sprawowaniu zarządu w życiu codziennym, z konieczności w sposób nieunikniony spoczywa w rękach urzędników" (cyt. za Filipowicz 2002, s. 364). W podobnym duchu wypowiada się współczesny badacz relacji polityka-biurokracja Robert Putnam (1973). Jego zdaniem we współczesnych, złożonych społeczeństwach Zachodu rządzą biurokraci. Dzieje się tak ze względu na wiedzę techniczną, a także ze względu na wiedzę o realnych ograniczeniach polityki, jaką dysponują biurokraci. Mają oni dominujący wpływ na konstruowanie agendy decyzyjnej i kształtu ustaw.

Dla prowadzonych tu analiz istotne jest zatem to, że Weber opisując zjawiska dostrzegane także we współczesnych teoriach biurokracji, umieszczał je na szerokim tle historycznym i jednocześnie głębiej wchodził w analizę specyfiki biurokracji (stworzył jej powszechny paradygmat), ściśle łączył ją z analizą natury polityki, uważał, iż profesjonalizacja zawodu polityka i profesjonalizacja zawodu urzędnika to długotrwałe, równoległe procesy (Weber 1998, s. 67) ${ }^{6}$. Rozrost biurokracji w „demokracjach wielkiego państwa” uznawał za koniecz-

\footnotetext{
5 Elżbieta Skotnicka-Illasiewicz (2014) przedstawia urzędników jako modernizatorów, którzy szybko się uczą „nowoczesnego porządku” Unii Europejskiej i wdrażają ten porządek.

${ }^{6}$ Weberowski model biurokracji jest poddawany krytyce jako nie $\mathrm{w}$ pełni adekwatny „w sytuacji radykalnych zmian społecznych i gospodarczych po drugiej wojnie światowej" (Hausner 2008, s. 16). Jednak Oscar Oszlak (2005, s. 489) po dokonaniu przeglądu współczesnych definicji biurokracji przyznaje, że „najbardziej nieodpartą definicję sformułował Max Weber”.
} 
ność i - podobnie jak współcześni badacze - twierdził, że „rozwój warstwy urzędników zawodowych stał się przeznaczeniem wszystkich nowoczesnych demokracji" (Weber 1998, s. 145). Dostrzegał przy tym nie tylko płynące z tego korzyści, ale także zagrożenia dla polityki demokratycznej.

$\mathrm{Na}$ znaczenie biurokracji w procesie „odczarowywania” świata, w tym przede wszystkim sfery polityki, rzuca światło również Weberowska koncepcja typów legitymizacji, związanych z typami panowania. We współczesnym świecie miejsce tradycji i charyzmy w legitymizowaniu władzy politycznej zajmuje legalność. W „odczarowanym świecie” panują zatem bezosobowe normy prawa stanowionego; działanie podlega racjonalnym regułom kalkulacji, biurokracja staje się nośnikiem tego racjonalnego porządku rzeczy, wkracza do polityki na przykład przez biurokratyzację machin partyjnych. Teoretycznie administracja jest składową władzy wykonawczej, zasobem elity politycznej — można stwierdzić, że jest wykonawczą częścią władzy wykonawczej. Dzięki administracji o góln a polityka rządu nabiera wymiaru k onkret n ego, abstrakcyjne idee polityczne przeobrażają się w realne rozwiązania prawne. Polityka zatem wyznacza cele, a administracja dobiera racjonalne środki ich realizacji. Wyznaczanie celów politycznych (ogólna polityka) ma / powinno mieć podstawy aksjologiczne, administrowanie nie musi być nakierowane na wartości, jego racjonalność wyraża się „tylko” w doborze odpowiednich środków realizacji.

W rzeczywistości ów splot polityka-administracja oraz relacja między elitami urzędniczymi a elitami politycznymi w aspekcie podziału zadań na polityczne formułowanie celów i biurokratyczne dobieranie środków są oczywiście bardziej skomplikowane. Współcześni badacze pokazują współzależność obu segmentów elit w wymiarze instytucjonalnym oraz zlewanie się logik działania, gdyż „sztuczny podział między administracją i polityką słabnie”, a osoby, które zajmują się administrowaniem „podejmują decyzje administracyjne, kierując się racjami politycznymi” (Peters 1999, s. 19). Samo zaś „mówienie o niezależności administracji politycznej od systemu politycznego jest hasłem politycznym" (Żyro 2006, s. 166)

Wyjściowa dychotomia polityka-administracja może być różnie problematyzowana i w zróżnicowany sposób konkretyzowana badawczo. W przywoływanym tu badaniu dychotomia ta była sondowana ostrożnie i pośrednio, poprzez metaforyczne pytanie o wpływ „rytmu politycznego” na pracę respondenta ${ }^{7}$. Podobnie jak $\mathrm{w}$ innych pytaniach intencją badaczy było wywołanie narracji związanej z własnym doświadczeniem respondenta. Termin „rytm polityczny” użyty w dyspozycjach do wywiadu otwartego był w założeniu terminem potocznym otwierającym dostęp do własnego doświadczenia respondentów i terminem metaforycznym, czyli apelującym do wyobraźni. Miał wywołać obraz reakcji na impulsy płynące ze sfery polityki do sfery administracji. Respon-

7 Warto przypomnieć, że relacja polityka-administracja jest oświetlana jednostronnie, $\mathrm{z}$ perspektywy elit administracyjnych. 
denci istotnie mówią językiem własnego doświadczenia, nie zaś językiem teorii (np. teorii zarządzania), z którymi musieli się zetknąć, choćby w trakcie szkoleń, i budują własne pomysłowe metafory ${ }^{8}$. Czasem sygnalizowany jest rozziew między tym, czym teoretycznie powinni się zajmować, a tym, co faktycznie robią: Chętnie bym pani opisała to, co $w$ teorii powinno być tutaj [śmiech], natomiast to, od strony praktycznej, niestety, to jak zawsze, a może nawet bardziej niż zawsze, sprawy bieżace sa ważniejsze od spraw ważnych [R. 20].

Trzeba jednocześnie zaznaczyć, że pytanie o „rytm polityczny” sprawdziło się jedynie częściowo, uzyskany materiał jest dość skąpy, jeśli porównać go na przykład $z$ analizowanym $w$ dalszej kolejności pytaniem o „misję" ${ }^{9}$. Trudność "dyplomatyczną" związaną z wymogiem neutralności i lojalności urzędnika ilustruje następujący przykład: Nie wiem, na ile mogę się tutaj, jak powiem, w czym pracuje, to zaraz będzie wiadomo, jak mam na imię i nazwisko, więc to nie będzie tutaj $\dot{z}$ adna anonimowa ankieta. Nie wiem, co mam powiedzieć [R. 44].

Niżej przytoczone cytaty, pierwszy - ogólnikowy, drugi - bardziej konkretny, stanowią przykładowe ujęcia przez naszych respondentów relacji polityka-biurokracja: Różnie się o tym mówi! To zależy od ministerstwa. Zależy od kierownictwa. Zależy od tego, skąd dany osobnik, który zastanawia się nad tym, czy zmiany będa miaty na niego wptyw czy nie [R. 33]; W ogóle polityka ma duży wptyw na realizowana przeze mnie prace, $z$ tego względu, że $w$ ministerstwie część stanowisk jest politycznych po prostu. Ja jestem na stanowisku urzędniczym, natomiast oczywiście później wyżej, wiceministrowie czy ministrowie, to sa stanowiska polityczne, więc oni realizują politykę partii czy politykę rządu [R. 34].

Wypowiedzi respondentów dają jedynie ogólny pogląd na to, w jaki sposób „polityka” pojawia się w ich życiu zawodowym. Lektura tych wypowiedzi zaskakuje różnorodnością „rozszyfrowywania” metafory rytmu politycznego i definiowania polityki. Zróżnicowana (choć mało uchwytna) wydaje się też aura emocjonalna towarzysząca narracji. Wyobrażenie o wpływie polityki i jej obecności w pracy elity administracyjnej dają pojęcia-skojarzenia z polityką i rytmem politycznym. Polityka w opisie respondentów pojawia się jako:

— atmosfera niepewności i niepokoju towarzysząca zmianom na stanowiskach politycznych i zmianie ekipy rządzącej;

— atmosfera dobrej współpracy, wzajemnego zrozumienia;

8 Zaledwie $\mathrm{w}$ dwóch przypadkach widoczna jest, inspirowana teorią (i wynikająca z porównania), krytyka biurokracji w Polsce, w jednym przypadku chodzi o nadmierną (w porównaniu z modelem brytyjskim) polityzację, w drugim — o ,absurdalny” brak zakładanej w teorii public management samodzielności kadry kierowniczej.

${ }^{9}$ Istnieją powody, aby sądzić, że pytanie mogło być trudne „poznawczo” i kłopotliwe z powodów „dyplomatycznych”. Jest to po części wynik zastosowanego narzędzia; osoby przeprowadzające wywiady miały pewną swobodę w zadawaniu pytań pogłębiających zagadnienie i stosunkowo często po prostu pomijały pytanie o wpływ „rytmu politycznego” na pracę. Można odnieść wrażenie, że nie doceniły wagi zagadnienia albo, wyczuwając opór respondentki/respondenta, nie drążyły tematu. 
- naciski, zawirowania, turbulencje;

— siła zewnętrzna, która potencjalnie powoduje odwołanie ze stanowiska;

- zagrażające stabilności działanie wewnątrz samego ministerstwa (restrukturyzacja, likwidacja departamentu — dużo się o tym mówi; jest to częsty temat plotek);

- psucie pomysłów decyzji po przejściu przez etap polityczny (podczas którego uwzględnia się wiele interesów);

- początkowy, udzielający się urzędnikom zapał po zmianie ministra, który szybko mija;

- czynnik modelujący działania ze względu na orientację (liberalną, prospołeczną i konkretną opcję polityczną rządu);

— sfera, z której płynie szansa na docenienie działań urzędnika.

Głębsza analiza rozproszonych i różnorodnych wątków wywołanych pytaniem o politykę pozwala na wychwycenie powtarzających się schematów tworzących pewien wzór opisu relacji polityka-administracja (polityk-urzędnik).

Polityka jako „z w a ri ow a ne lot ni s ko” - taki obraz nasuwa się jednemu $\mathrm{z}$ respondentów $\mathrm{w}$ trakcie opisu ingerowania polityki $\mathrm{w}$ jego pracę. $\mathrm{W}$ innym wywiadzie doświadczenie styku polityki z urzędowaniem przynosi skojarzenie falujacego morza. Polityka jawi się jako obszar dynamiczny, z którego płyną różnorodne, czasem nieprzewidywalne, czasem nieracjonalne zadania do szybkiego wykonania. Niedoczas; nagłe wrzutki; prace do wykonania z godziny na godzine to kolejne pojęcia-skojarzenia dla rytmu politycznego Te skojarzenia pokazują, że świat polityki pracuje na innych, szybszych obrotach niż świat biurokracji, narusza rytm pracy urzędnika, wymusza na nim pośpiech głównie w drobniejszych zadaniach, ale także w procedowaniu ustaw: Regulamin to przewiduje, $n p$. pan premier może zadecydować, że będzie skrócona ścieżka legislacyjna [...] tutaj pan premier i osoby, które upoważni, sa jedynymi osobami, które coś takiego moga zrobić [...] no to jest tak, że sa jakieś reakcje polityczne, które wynikaja z aktualnego stanu opinii publicznej. I jeżeli ktoś ma kompetencje do tego, żeby zareagować, to musi wymyślić sposób reakcji, który będzie możliwy do zrealizowania w miarę krótkim czasie [R. 29]. Szybka reakcja urzędników to pomoc w sytuacji, gdy rząd dostat się pod ostrzat i trzeba szybko reagować, co oznacza różne nagłe zlecenia do wykonania: [...] często, tak dosłownie z godziny na godzine, wpadaja polecenia wykonania jakiegoś, jakichś tez do wystapień ministra czy któregoś zastępcy ministra [...] bo jak mamy godzinę, za godzine minister gdzieś, no to się skleca coś, żeby byto bez mówienia, przekazywania, sprawdzania, poprawiania. Po prostu od razu, od razu, żeby szybko [R. 47]; [...] dlatego wydaje mi się, że dużo trudniej jest linearnie zdefiniować to, co chcemy osiagnać i powiedzieć, że za trzy lata chcemy być tam i tam [R. 49].

Trzeba zaznaczyć, że zarówno permanentna praca w niedoczasie, jak i wrzutki, prace $z$ godziny na godzine są traktowane jako rzecz normalna, co nie znaczy, że pożądana i racjonalna. Nie odnosi się wrażenia, że respondenci się skarżą czy oskarżają polityków o taką sytuację. Pojawia się wszakże niepokój o jakość pospiesznie wykonywanej pracy, a nawet jej sensowność: Mam taką obawę, czy 
wszystko, co zrobimy, to jest dobrze przemyślane, czy my nad tym wszystkim panujemy, czy można nad tym panować [R. 2].

$\mathrm{Na}$ inne - poważniejsze - zagrożenie płynące ze sfery polityki wskazuje respondentka, wedle której obróbka polityczna psuje decyzje. W tym wypadku nie chodzi o nerwowy, przyspieszony, rytm pracy, zagrażający jej jakości/fachowości, ale o głębsze psucie sensownej decyzji (ustawy) - decyzja traci sens, a respondent poczucie kontroli, w efekcie decyzja nie rozwiązuje problemu: Natomiast fakt wptywania na te decyzje wtaśnie wielu instytucji, wielu jakichś poglądów politycznych, tego takiego ucierania, dogadywania się, to może wręcz wysadzić dobry pomyst. Albo decyzja, która gdzieś tam na końcu się pojawia, już jest nieefektywna. Jakaś jest, ale ona już nic nie załatwi [R. 12].

Najczęściej jednak metafora „zwariowanego lotniska” odniesiona do relacji urzędnik-polityk (administracja-polityka) oznacza, że urzędnik w każdej chwili może zostać zaprzęgnięty przez polityka do nagłych zadań, naruszających biurokratyczny rytm pracy. Może to zaburzać przebieg pracy, zagrażać jej rutynie, a nawet racjonalności. Można się domyślać, że prace wykonywane $z$ godziny na godzinę nie spełniają wymogu fachowości. Jakie „samopoczucie” członków elity administracyjnej towarzyszy tej narracji? Czy zagraża ono ich autonomii? W tym schemacie opisu relacji polityk-urzędnik „podporządkowanie” urzędników jest konsekwencją presji wywieranej przez polityków i nerwowego rytmu polityki. Respondenci odbierają jednak ten rodzaj oddziaływania jako normalny i naturalny. Co więcej, czerpią satysfakcję z poczucia sprawności w reagowaniu na nagłe wrzutki i umiejętności poruszania się po zwariowanym lotnisku. Potencjalne napięcie na tej linii jest „niwelowane” przez kompetencje urzędnika, od polityka oczekuje się uznania tych kompetencji.

Samo podporządkowanie - choć uświadomione - nie narusza poczucia autonomii respondentów i jest raczej postrzegane jako współpraca z politykami oraz podporządkowanie się polityce i meritum niż politykom i ich woli.

Podporządkowanie, podział ról - to drugi schemat interpretacyjny rytmu politycznego. $W$ tym schemacie, podobnie jak $\mathrm{W}$ omawianym wcześniej, respondenci mówią o podporządkowaniu. O ile jednak poprzednio chodziło raczej o nagłe wtargnięcie świata polityki w świat urzędniczy, o tyle tutaj chodzi o ustalony, prawnie ugruntowany podział ról. W tym schemacie rozszyfrowania pytania o rytm polityczny widoczna jest (pozbawiona napięć na linii polityka-administracja) akceptacja wykonawczej roli urzędników; elity administracyjne grają wedle nut ułożonych przez elity polityczne: Ja zawsze gdzieś z tytu głowy mam taka myśl, że ja po prostu jestem urzędnikiem, który musi [...] jakby jest posadzony przed fortepianem, dostat nuty $i$ musi zagrać to, co dostat. Ja nie dostrzegam takich [...] przeszkód, problemów [R. 39]; [...] podstawowe zadania: wyznaczanie kierunków przede wszystkim. W porozumieniu oczywiście z ministrem, bo to minister wyznacza kierunki działania, ale jakby rozmawiamy na ten temat [R. 38]; Rytm polityczny na pewno, zmiana ekipy rządzacej, zmiana ministra, oznacza równiė̇ zmiany w podejściu, bo [...] każdy minister reprezentuje inna osobowość, inna opcje 
polityczna, inne cele. W związku z tym musimy po prostu dostosować się, ale też my działamy zgodnie $z$ prawem. I tu jest rola urzędnika, że $w$ granicach prawa działa. Nawet jeśli minister uważa, że coś trzeba zrealizować, ale jeśli to wykracza poza możliwości prawne, to zwraca się uwage, że to jednak jest sprawa, która wykracza poza nasze możliwości [R. 3]; Natomiast te zmiany polityczne, to oczywiście, one powoduja przede wszystkim zmiany $w$ kierownictwie resortu $i$ często jest [...] jakaś zmiana kierunku działania. Ona nigdy nie byta jakaś drastyczna [R. 13].

Podobnie jak w poprzednim schemacie interpretacyjnym widoczne jest podporządkowanie polityce, akceptacja jej modelującego wpływu. Akceptacja podporządkowania wiąże się z „,̇ołnierską" specyfiką pracy urzędnika.

W odróżnieniu od poprzedniego schematu interpretacyjnego ingerencja „świata polityki” $\mathrm{w}$ „świat administracji” to ustalony prawnie schemat relacji, a (względnie) powolny „rytm polityczny” wyznaczają zmiany na stanowiskach politycznych. Do zmian personalnych, zmian kierunku polityki urzędnik musi się dostosować. Podporządkowanie interpretowane jest formalnie (w ramach prawnych), „drugą stroną medalu” jest gwarantowany prawem zakres autonomii.

Siła przetrwania - to kolejny typ interpretacji pytania o rytm polityczny (przetrwałam jedenastu czy trzynastu ministrów). Ten typ odbioru pojawiał się zaskakująco często, czyli można stwierdzić, że respondenci zdają sobie sprawę $z$ istnienia groźby utraty stanowiska spowodowanej polityką. $\mathrm{W}$ tym schemacie mieszczą się opowieści na temat zagrożeń związanych zarówno ze zmianą rządu / koalicji rządzącej, jak i ze zmianami na stanowiskach politycznych $\mathrm{w}$ resorcie. Respondenci, którzy w ten właśnie sposób zinterpretowali pytanie, nie opowiadali o sobie i własnych obawach. Pytanie posłużyło do zaznaczenia własnej „siły przetrwania”, podbudowania wizerunku respondenta jako osoby kompetentnej. Zagrożenie ma dotyczyć „innych”, słabszych, mniej kompetentnych.

Jeśli za podstawę schematu uznać rozumowanie mnie polityka nie dotyka / nie dotyczy, to $\mathrm{w}$ jego obrębie pojawi się podtyp postrzegania polityki werbalizowany następująco: polityka jest poza mna; poglady polityczne mam dla siebie; mnie to nie dotknęło, nie odczuwam nacisków; jestem poza polityką; moje stanowisko jako wicedyrektora jest poniżej polityki. Tak prezentowane odcinanie się od polityki, redukowanie jej do prywatnych poglądów lub niedostrzeganie jej wpływów daje respondentom wyczuwalną satysfakcję, buduje poczucie własnej wartości.

A oto przykłady ilustrujące główny schemat „siły przetrwania”: Jeśli o mnie chodzi, to mnie nie dotknęto takie [...] ani nie miałem jakichś nacisków, czy jakichś takich, czy przy zmianach. Jestem dyrektorem $w$ czasie, kiedy PiS byt przy władzy, to po zmianie jakby nie [...] $w$ sensie takim merytorycznym nie odczułem żadnej zmiany [R. 5]; [...] liczyłam kiedyś ministrów dla ilu pracowałam, to wyszło mi coś między 10 a 13. Wliczając dwa razy Kaczyńskiego, który byt premierem, będac jednocześnie każdym ministrem $z$ osobna [R. 22]; Zmieniaja się ministrowie $i$ departamenty - ja się zajmuje tym samym [R. 24]; [...] żadne zakręty polityczne [...] nie dotknęty [R. 33]. 
Współdziałanie, podmiotowość sprawcza. Czwartym typem reakcji na pytanie o wpływ polityki było wydobywanie faktu współdziałania i współsprawstwa - podmiotowość społeczna i poczucie sprawstwa. Ilustracją empiryczną tego schematu jest cytat: Mnie najbardziej pasjonuje to, że „sam moge" [R. 12].

Podkreślanie samodzielności nie wyklucza partnerskiego współdziałania, dostosowanie się do polityki nie wyklucza autonomii: my tworzymy, współtworzymy politykę. Nikt jawnie nie podkreśla czy nie udobitnia przewagi „fachowców" nad politykami, ale takie sugestie się pojawiają: Jesteśmy też autorami projektu różnych form ustawy reprywatyzacyjnej, które miaty różny swój los. Ale te regulacje my tutaj przygotowujemy [R. 11]; Można powiedzieć, że od 1996 r. pracuje już samodzielnie, na swój rachunek, czyli pracując na stanowiskach kolejnych dyrektorów kolejnych departamentów [R. 10]; Anonimowe wspótsprawstwo. Brzmi to fantastycznie, kiedy styszę, że to, co tutaj zostało zainspirowane, jest wyktadane później wtaśnie $w$ formule już decyzyjnej przez inne osoby, przez szanowane gremia zarówno akademickie, jak i polityczne [R. 10]; [...] my tworzymy, wspóttworzymy politykę rządu. To takie naprawde grube sprawy [R. 18]; I to, co jest specyfika tego departamentu, to to, że wtaściwie będąc wspótkreatorami polskiej polityki zagranicznej [...] [R. 20].

Dla zrozumienia relacji polityka-administracja ważne jest ogólne wyczucie polityki, a zwłaszcza siły jej wpływu oraz usytuowania w codziennej pracy członka elity administracyjnej (jako sfery zewnętrznej, wewnętrznej lub mieszanej). Wypowiedzi na ten temat nie dają podstaw do formułowania stanowczych wniosków w kwestii autonomia-podporządkowanie; narracje są bowiem dość ogólnikowe i ilościowo skromne ${ }^{10}$. Polityka, jej nerwowy rytm, związany $z$ wyborami i zmianami na stanowiskach, oraz podatność na wpływy interesów i opinii mogą zagrażać przedmiotowo (racjonalności decyzji) i podmiotowo (sensowności pracy). Polityka sprawia, że praca przemienia się $\mathrm{w}$ „zwariowane lotnisko", co może, ale nie musi, zagrażać racjonalności pracy. Obawy takie są formułowane rzadko.

W dwóch typach narracji („zwariowane lotnisko” i „granie wedle nut”) wydobywane jest podporządkowanie, w pozostałych dwóch typach charakterystyki polityki i relacji polityka-administracja i polityk-urzędnik bardziej widoczne są inne - nastawione na autonomię - strategie legitymizacyjne. Nie znaczy to, że podporządkowanie nie ma mocy legitymizacyjnej, sprostanie nagle spadającym zadaniom jest źródłem poczucia wartości, tak jak może nim być „gra z nut”, a nie własne ich układanie. Charakterystyczne jest jednak poczucie własnej wartości, czerpane z wielu źródeł, co składa się na wyraźnie dobre samopoczucie członków elity administracyjnej, widoczne w jej relacji z elitą polityczną. Ogólnie biorąc, rytm polityczny - wyczuwalny i rozmaicie

10 Pewna refleksja pojawia się $\mathrm{w}$ następującej wypowiedzi: [...] ale jednak mimo wszystko nasze państwo jest mocno spolityzowane $i$ ta polityka się... To nie jest Wielka Brytania, a już na pewno to nie jest taka Wielka Brytania [R. 39]. 
rozumiany - nie zagraża samopoczuciu dyrektorów departamentów, a relacje świata biurokracji ze światem polityki pozwalają na budowę tożsamości oraz sprzyjają uświadomieniu sobie przez członków elit administracyjnych własnej odrębności i ujawnieniu własnych zasobów symbolicznych: kompetencji, podmiotowości sprawczej, autonomii. Nawet schemat „zwariowanego lotniska” nie służy krytyce polityki czy skardze na nią, ale akcentowaniu własnych kompetencji umożliwiających sprostanie zadaniu.

\section{MISJA I ODPOWIEDZIALNOŚĆ URZĘDNIKÓW}

Jak już wspomniałam, pytanie o „misję” zyskało wśród respondentów spory odzew. Narracje dotyczące misji są obszerne, wprowadzają też społeczny układ odniesienia. Badani wykraczają $\mathrm{w}$ nich bowiem poza wąsko rozumiany porządek instytucjonalny państwa, polityki i elity politycznej w kierunku swych społecznych identyfikacji grupowych (takich jak inteligencja / elita inteligencka). Odpowiedzi na pytanie o „misję" i „odpowiedzialność” oraz narracje dotyczące „rytmu politycznego" wzajemnie się uzupełniają, a kategorią spajającą oba wymiary jest „odpowiedzialność”.

Warto przypomnieć podstawowe rozróżnienie dotyczące odpowiedzialności, które sformułował niemiecki filozof Georg Picht (2011, s. 403): „Pojęcie odpowiedzialności ma podwójne odniesienie: odpowiadamy za coś lub kogoś oraz jest się odpowiedzialnym przed pewną instancją, zleceniodawcą, który jest źródłem odpowiedzialności - wybrany rząd jest odpowiedzialny przed swoimi wyborcami, urzędnik przed swymi zwierzchnikami".

Odpowiedzialność i etyka odpowiedzialności to kolejne ważne dla Maksa Webera pojęcie, które należy przywołać. Etyka odpowiedzialności stanowi dla niego probierz oceny polityka, jest kluczowa dla typu "polityka z powołania”. Polityk z powołania to przywódca, którego działalność nie może się ograniczać do administrowania, a jego honor wyraża się w braniu odpowiedzialności za skutki własnych działań, także za działalność podlegających mu urzędników. I tu pojawia się ważne rozróżnienie: przywódca polityczny a urzędnik-fachowiec: urzędnik ma działać bezstronnie, nie może walczyć (a to robi zawsze przywódca polityczny), nie może opowiadać się po czyjejś stronie (Weber 1998, s. 75). Czy zatem urzędnik jest wolny od dylematów moralnych, niemal nieuchronnych w działaniu polityków? Honor urzędnika, twierdzi Weber (1988, s. 75), polega na tym, aby wykonać każde polecenie, także niesłuszne, na odpowiedzialność przełożonego: „tak jak gdyby odpowiadało ono własnemu przekonaniu urzędnika; bez tej w najgłębszym sensie moralnej dyscypliny i zdolności urzędnika do zaparcia się samego siebie rozpadłby się cały aparat”. Polityk, kierujący się etyką odpowiedzialności, musi być zdolny do „zaparcia się samego siebie" w imię celów politycznych. Powinnością zawodową urzędnika jest natomiast zdolność do „zaparcia się samego siebie” w imię spoistości instytucji. Politycy pozostają jednak na pierwszej linii kontaktów z obywatelami, biorą 
odpowiedzialność za wybór celów oraz skutki swoich działań i skutki działań urzędników. Narracje naszych respondentów nie ujawniają Weberowskich (czy innych, na przykład związanych z korupcją czy lobbingiem) dylematów moralnych związanych $z$ byciem urzędnikiem, z czego nie wynika, że są oni od nich wolni. Ich „dobre samopoczucie” związane jest raczej z tym, że to politycy są na pierwszej linii kontaktów z opinią publiczną i oni faktycznie biorą odpowiedzialność przed społeczeństwem za działania urzędników. Mimo skarg (nielicznych) na brak zrozumienia społecznego i głupotę mediów urzędnicy znajdują się $\mathrm{w}$ komfortowej sytuacji w porównaniu z politykami: odpowiedzialność za skutki ich działań spada na polityków.

Pojęciem ściśle związanym z odpowiedzialnością i autonomią urzędników jest „misja”. We współczesnym dyskursie publicznym (a także w dyskursie naukowym) misja ma dwie podstawowe konotacje: tradycyjną i nowoczesną, „zaczarowaną" i „odczarowaną". W ujęciu tradycyjnym misja jest utożsamiana z posłannictwem, służbą społeczną, poświęceniem, ważnym zadaniem do spełnienia, szczególną odpowiedzialnością. „Odczarowany”, pragmatyczny sposób pojmowania misji oferuje socjologia organizacji: „Misja jest precyzyjnym wyrażeniem - w języku zrozumiałym dla pracowników i otoczenia organizacji dalekosiężnych zamierzeń i aspiracji organizacji. Misja jest sformułowaniem wizji firmy na użytek strategii" (Obłój 2001, s. 235). Pragmatycznie zdefiniowana misja sprawdza się w organizacjach nastawionych na generowanie zysku; państwo i jego organy nie są taką organizacją ${ }^{11}$. „Biurokracja publiczna działa w sferze politycznej, gdzie ceny, zyski, straty są kalkulowane w zróżnicowanych i skomplikowanych kategoriach władzy, polityki i priorytetów programowych" (Żyro 2006, s. 167). Jeden $z$ respondentów daje w tej sprawie ironiczny komentarz: Misja $i$ wizja? Tu byta kiedyś jedna $z$ firm audytorskich, która badała $w$ naszym ministerstwie misję $i$ wizję. Nic $z$ tego nie wyszło jakoś [śmiech]. Tak że nie chciatbym tutaj szerzej omawiać tego tematu [R. 3].

Bogdan Mach i Stanisław Mocek (2010) w studium poświęconym inteligencji we współczesnej Polsce udowodnili trwałość tradycyjnego pojmowania jej zadań, trwałość inteligenckiej misji w nowym ustroju. Przeprowadzona przez nich analiza opinii publicznej (ogólnej i w segmencie inteligencji) przekonuje, że inteligencja to nadal (do pewnego stopnia) grupa „wybrana”, od której można oczekiwać „czegoś więcej”. To „więcej” oznacza, że oprócz wykonywania pracy zawodowej inteligent powinien dawać z siebie „coś ponadto”, pełnić jakiś rodzaj „służby społecznej”. Opinia publiczna przypisuje też inteligencji specjalne, służebne relacje z władzą polityczną. Inny badacz inteligencji, Jerzy Mikułowski Pomorski (2005), wyróżnił trzy kategorie inteligencji: „sumienie narodu”, „ci, co odwołują się do wartości inteligenckich” oraz „nowi

11 Problem ten - nieobecny w świadomości naszych respondentów, z jednym wyjątkiem — jest dostrzegany w nowszych teoriach zarządzania. Andrew Heywood (2006) omawia teorie i praktyki zarządzania pozwalające na konkretne kalkulacje efektów działań biurokracji. 
profesjonaliści”. W powracającej co pewien czas w Polsce debacie publicznej na temat kondycji i roli inteligencji stosunkowo rzadko pojawia się figura urzędnika. Jeden z uczestników tej debaty, Bronisław Świderski (2000), stwierdził: „Często powtarza się opinię, że urzędnicy nie są bynajmniej właściwymi reprezentantami inteligencji, której prawdziwym przedstawicielem ma być pisarz, filozof, nauczyciel, artysta i uczony". Cytowany autor podjął też kilka ważnych kwestii: po pierwsze, podważył pogląd mówiący o dwóch tradycjach polskiej inteligencji: biurokratycznej - złej i ułomnej (z powodu długotrwałego braku suwerennej państwowości) oraz oświeconej (liberalnej); po drugie, pokazał niepokoje Zachodu przed przystąpieniem Polski do Unii Europejskiej dotyczące (nie)przygotowania naszych urzędników; po trzecie, przypomniał ciężar schedy romantycznej polegający na „oddzieleniu języka inteligencji od polityczno-administracyjnej praxis" (Świderski 2000) ${ }^{12}$. Zdaniem badaczy (zob. np. Ajnenkiel 1977; Świderski 2000; Kamiński 2014) przezwyciężenie „romantycznej schedy" oraz likwidacja podziału na prawdziwych, obdarzonych misją inteligentów oraz urzędników nastąpiły w okresie II Rzeczypospolitej. Inteligenci z poczuciem odpowiedzialności za społeczeństwo i państwo zajęli stanowiska urzędnicze.

Co zatem o „misji” i „odpowiedzialności” sądzą przedstawiciele elit administracyjnych? Czy ich wypowiedzi wpisują się w wersję „zaczarowaną” i „tradycyjno-inteligencką”, czy też „odczarowaną" i „pragmatyczno-menedżerską"?

Nasi respondenci raczej nie aspirują do bycia „sumieniem narodu”. Jak jednak zobaczymy, większość z nich nie traktuje swojej pracy jako czegoś zwykłego. Jest ona specyficzna, zawiera pewien naddatek ponad (czy poza) wymagania zawodowe. Sposoby przejawiania się tego „naddatku” w wypowiedziach badanej zbiorowości dyrektorów departamentów będę się starała zidentyfikować. Jak są rozumiane i operacjonalizowane, jaka otoczka emocjonalna przy okazji się ujawnia? Można by pomyśleć, że w „odczarowanym świecie” biurokracji rządzą specjaliści i nie ma miejsca na „zaczarowane słowa”. Pytanie, w którym pojawiło się słowo „misja”, wywołało komentarze związane z rozumieniem samego pojęcia.

Najprostszy (rzadki) typ reakcji to negacja, odmowa użycia słowa „mis ja” w jego „zaczarowanym”, podniosłym znaczeniu: Nie. W żadnym wypadku nie postrzegam tego jako misji. To jest wykonywanie obowiązków, które zostaty

12 W debacie tej, prowadzonej w 2000 roku na łamach magazynu „Rzeczpospolitej” „Plus Minus”, wzięli udział: Bohdan Cywiński, autor legendarnej książki Rodowody niepokornych (Inteligencji nekrologi przedwczesne, nr 16), Bronisław Wildstein (Przeciw skansenowi, nr 19), Zdzisław Najder (Od modelu stużby do nostalgicznego mitu, nr 22), Kazimierz Krzysztofek (Odzyskać władzę nad symbolami, nr 24), Andrzej Paszewski (Postuga myślenia, nr 26), Janusz Majcherek (Nowe elity na nowe czasy, nr 28), Stefan Bratkowski (Dzieci Stanisława Konarskiego, nr 30), Jan Pruszyński (Ograniczyć, wyprzeć i zlikwidować..., nr 32), Bogumił Luft (Perypetie etosu stużby, nr 34) oraz Jerzy Surdykowski (Inteligencja ma kolosalna przysztość, nr 37). 
mi powierzone. Urzędnik po prostu jest po to, żeby administrować krajem, $i$ to jest nasza rola [R. 3].

Drugi, bardziej popularny typ reakcji to pato s k on trolowany. Dostrzegana jest swoistość pojęcia, jego odświętny charakter - w celu złagodzenia takiej interpretacji respondenci stosują formuły wyrażające dystans i osłabiające czy osłaniające patos: ja nie lubię używać wielkich stów; to jest takie bardzo górnolotne; nie chcę, żeby to tak szumnie zabrzmiato; będzie takie, nazwijmy to, sformułowanie pompatyczne; nie wiem, czy to jest misja, bo misja to jest strasznie duże stowo, ale o to $w$ gruncie rzeczy chodzi [R. 6].

Zaznaczenie dystansu połączone jest z akceptacją terminu „misja” do opisu zadań. Co więcej, opinie na ten temat są wypowiadane w taki sposób, że z opisu pełnionych zadań wynika „misja”.

W części narracji można też dostrzec patos niekontrolowany, a respondenci sami siebie $\mathrm{w}$ związku $\mathrm{z}$ tym nazywają romantykami, idealistami. Oto wypowiedź jednej z respondentek: Jedna sprawa - wszelkiego rodzaju przedsięwzięcia, które właśnie stuża temu, aby wysoka kultura mogła docierać do wielu odbiorców, nie tylko $z$ dużych ośrodków. Druga sprawa to jest ta, aby w miarę wyodrębnić i zachować odrębność, nie tylko instytucjonalna, ale odrębność $w$ sensie pewnego spogladania na instytucje, które prowadza działalność artystyczna, że nie moga być traktowane jak zwyczajne zakłady pracy, musza być, posiadać nieco inny system prawny, ale nieco inny, to wynika $z$ moich wieloletnich doświadczeń praktycznych. Kolejnym elementem, który uważam, że jest istotny, to swego rodzaju aktywizacja tych stabszych ośrodków kultury [R. 6].

Najbardziej popularny sposób odniesienia się do słowa „misja” to jego aprobata bez komentarza ujawniającego emocje lub inne asocjacje rozwijające pojęcie: Ja to mam i pewnie wielu to ma. Jest takie poczucie jakiejś takiej misji; [...] ja mam swoje, że tak powiem, własne misje i zdecydowanie tak; służe państwu, natomiast ta misja jednak jest generalnie $w$ tym charakterze pracy [R. 37].

A jak jest rozumiana i opisywana (rozszyfrowywana) treść owej misji, jej zawartość? Można wyróżnić cztery wyraźniejsze typy narracji:

- misja jako kreowanie i ulepszanie rzeczywistości (polityki, tworzenie polityk, pisanie ustaw, wprowadzanie idei w życie, przekładanie ogólnych zasad na konkretne działania);

- misja jako służba państwu (dobremu funkcjonowaniu instytucji, interesom i wizerunkowi państwa, jego bezpieczeństwu, praca na rzecz ministrów, premiera, prezydenta);

— misja jako służba społeczeństwu, odpowiadanie na interesy społeczne;

- misja jako poświęcenie kosztem innych spraw, zapał do pracy.

Misja jako kreowanie i ulepszanie rzeczywistości. Ilustracją tego schematu interpretacyjnego jest wypowiedź: przyczyniam się do zmiany kraju na lepsze. Ten schemat percepcji własnej pracy poprzez kategorię misji jest wyraźnie zarysowany i obejmuje szereg aktywności opisywanych jako kreowanie instytucji państwowych, regulowanie pewnego zakresu codziennej rzeczywi- 
stości, tworzenie prawa, tworzenie polityki, współtworzenie polityki i polityk sektorowych, współudział w decyzjach, w pisaniu ustaw, wypracowywanie stanowiska do decyzji itd. Respondenci są świadomi że należą do nielicznej grupy osób, które decydują o sprawach ważnych dla wszystkich bądź dla wielu. My to wymyślamy, a potem to powszechnie obowiazuje; tworzymy przepisy dla dużych grup społecznych [R. 15]. I tu można przytoczyć cytaty dokumentujące świadomość elitarną: tworza nieliczni, obowiąuje wszystkich; z naszego bocianiego gniazda widać inaczej; wymyślają nieliczni, dotyczy wielu, dotyczy całego społeczeństwa; to jest przede wszystkim, to takie kreowanie, tak naprawde takiej codziennej rzeczywistości catego państwa [R. 15]. Jesteśmy wspótkreatorami polskiej polityki zagranicznej [R. 20]; krótko mówią, zajmujemy się bezpieczeństwem kraju, kreując nasza politykę $w$ tym zakresie na forum międzynarodowym [R. 21]; poprzez kolejne tam reorganizacje caly czas kieruje jednostkami organizacyjnymi, które - tak się ztożyto, $\dot{z}$ e - sam tworze. To znaczy dostaje taka misje, no $i$ po prostu staram sie $z$ tego wywiazywać [R. 10]; Przygotowuje strategie „Sprawne państwo” [R. 49]. W tym typie narracji na pierwszy plan wybija się kreacyjna rola własna, widoczne jest poczucie, że się tworzy coś nowego, ważnego i dotyczącego dużej zbiorowości.

Misja jako służba państwu. Przykładem takiego rozumienia misji są następujące wypowiedzi: Chce stużyć państwu [R. 11]; nie chce, żeby to tak szumnie zabrzmiato, ale to jest praca na potrzeby państwa [R. 8]. Tak syntetyczne formuły mogłyby się znaleźć właściwie w każdej narracji - wszyscy urzędnicy z definicji służą przede wszystkim państwu. I rzeczywiście stosunkowo często misja państwowa wysuwa się na pierwszy plan, respondenci do niej „instynktownie" się odwołują. Tak pojmowana misja obejmuje wiele ważnych zadań, werbalizowanych jako: funkcjonowanie instytucji państwa, służenie jego interesom, praca na rzecz wizerunku państwa, siły państwa, materializowanie polityki, wdrażanie polityk sektorowych czy po prostu realizowanie zadań departamentu itd. $Z$ opisu zadań dowiadujemy się, że nasi respondenci wykonują w pracy to, co należy do każdego stanowiska kierowniczego (zarządzanie, doradzanie, inspirowanie, narzucanie, wpływanie, kontrolowanie, reprezentowanie, pośredniczenie $\mathrm{w}$ relacjach góra-dół, analizowanie i opracowywanie ważnych dokumentów, ustaw itd.). Specyfika pracy, która pozwala używać wielkich słów, wynika z zakresu odpowiedzialności i ciężaru gatunkowego wykonywanej pracy. Jeden z respondentów ujął to następująco: to są grube sprawy. A oto pełniejsze rozwinięcie jego narracji: Głównym odbiorca sa oczywiście ministrowie tutaj, ale też pan premier [...]. W zwiazku z tym, że sytuacja gospodarcza jest jaka jest $i$ tematy ekonomiczne dominuja na agendzie Unii Europejskiej, to zwykle zajmujemy sie takimi tematami, maja bardzo duże znaczenie dla interesów gospodarczych Polski czy dla interesów politycznych Polski. To takie naprawde grube sprawy [R. 18]. Inny respondent stwierdził: Oczywiście im wyższy szczebel, tym wyższy poziom odpowiedzialności. My, pracownicy urzędów czy administracji rzadowej, samorzadowej czy nawet lokalnej, odpowiadamy za to, żeby pewne 
obszary działalności państwa funkcjonowaty na tyle sprawnie, na ile jest to możliwe. I myśle, że ta praca jest bardzo odpowiedzialna praca $i$ myśle, że jest trochę niedoceniana [R. 14].

Kolejne wypowiedzi ilustrują różne aspekty służby na rzecz państwa: Moja misja polega na zabezpieczeniu potrzeb państwowych jednostek organizacyjnych, czyli mówiąc o państwowych jednostkach organizacyjnych, mam na myśli osiemdziesiąt pare instytucji, poczynajac od instytucji panstwowych typu Kancelaria Sejmu, Senatu, Prezydenta, Trybunat Stanu, Sąd Najwyższy, a kończac na takich instytucjach, jak Kancelaria Premiera czy rządowe [R. 10]; Naszym zadaniem jest podnoszenie rangi i zagwarantowanie nam bezpieczeństwa poprzez działanie na forum międzynarodowym [R. 21]; Nie można sobie pozwolić na bylejakość. Za każdym razem, jak gdzieś występujemy publicznie, to reprezentujemy ministra [R. 13]; Nasze ministerstwo głównie wspomaga w konkretnych decyzjach politycznych Kancelarię Prezydenta [R. 17]; Odbiorcami pracy tego departamentu jest kierownictwo resortu, to jest minister $i$ wiceministrowie. A to ministerstwo dziata po to, żeby Polska sie promowata poprzez te aktywność, która tam prowadzimy [R. 14]; Naszym zadaniem jest podnoszenie rangi $i$ zagwarantowanie nam bezpieczenstwa poprzez dziatanie na forum międzynarodowym [R. 21].

Misja jako służba społeczeństwu. Ten typ misji wymaga uwag wprowadzających. To, czy i w jaki sposób służba społeczeństwu jako kategoria pojawia się $\mathrm{w}$ narracji, zależy nie tylko od wyobraźni respondenta, ale także od charakteru departamentu. Departamenty określane przez respondentów jako „horyzontalne” czy „regulacyjne” pracują na rzecz instytucji państwowych i polityków. W takich wypadkach schemat „misja jako służba społeczeństwu” się nie narzuca. W innych departamentach („pionowych”) odbiorcami są „zwykli ludzie”, „partnerzy społeczni”, na przykład grupa pielęgniarek, i wtedy ten schemat jest chętnie przywoływany. Niezależnie od zadań departamentu część respondentów wprowadza rozróżnienie między „odbiorcą bezpośrednim” a „odbiorcą docelowym”, czyli bezpośrednio jest to praca na rzecz instytucji państwowych i polityków (ministra, premiera), ale docelowo oznacza „służbę społeczeństwu".

Z materiału empirycznego można wybrać następujące wypowiedzi: Ludziom, ludziom, ludziom. Ludziom, czyli naszemu spoteczeństwu. Ja staram się tak na to patrzeć [...] moim programem jest takie zarzadzanie obecnym programem dla Polski wschodniej [R. 42]; Przede wszystkim ludziom. Wszystko, co ministerstwo robi, robi po to, żeby zrealizować swoja misje $i$ cel strategiczny, który ministerstwo posiada. Akurat $w$ tym przypadku to jest pewien stan fizyczny $i$ dobrostan spoleczeństwa [R. 14]. Bo to też tutaj chodzi o to, żeby system informatyczny, czy rejestr, budować tak, żeby to nie byt tylko zbiór danych stużacych organom administracji, ale żeby on świadczyt jakieś ustugi powszechnie dostępne wszystkim obywatelom [R. 15]; [...] ta praca odbywa się na rzecz takiej grupy zawodowej, jaka sa pielegniarki i ona nie może po prostu... znaczy, $w$ tej pracy nie może nie być tej misji [R. 37]; To też taka moja rola trochę edukacyjna, $\dot{z}$ eby tlumaczyć, dlaczego to jest potrzebne. Ale to sie zdarza, to sie zdarza - brak 
takiego zrozumienia $w$ sytuacji [R. 39]; Moja praca ma, przynajmniej w mojej ocenie, stużyć temu, żeby ludzie, którzy utrzymują się z pracy swojego umystu czy wyobraźni, mieli za to pieniadze [R. 7]; I sa to sprawy, można powiedzieć, bardzo bliskie ludzi, spoteczeństwa [R. 27].

Misja jako zapał/pasja/poświęcenie w pracy. Ten schemat rozszyfrowania pojęcia misji $\mathrm{w}$ odniesieniu do własnej pracy jest $\mathrm{w}$ badanej zbiorowości stosunkowo rzadko stosowany. Jeśli jednak do tych bezpośrednich narracji dodamy opisywany wcześniej schemat „zwariowane lotnisko”, to łatwo dostrzec, iż także w tym aspekcie pracę charakteryzuje „naddatek” — pasja związana z poczuciem pełnienia ważnej roli („pieniądze są źródłem satysfakcji, są w tle, ale to nie wystarczy"): Wydaje mi się, że w ogóle praca w UKIE [Urzędzie Komitetu Integracji Europejskiej] byta takim miejscem, gdzie byt bardzo duży zapał do pracy, pracowato się $w$ gronie osób bardzo młodych, które wierzyty $w$ ideę integracji. $W$ związku $z$ tym poświęcało się dla pracy bardzo dużo $i$ też [...] starało się bardzo dużo robić, dawać od siebie [R. 18].

Jak już wspomniałam, w autocharakterystykach dotyczących własnej pracy respondenci nie stronią od postrzegania jej jako misji w tradycyjnym tego słowa znaczeniu. Większość nie postrzega tego, co robią, jako „pracy jak każda inna".

Na koniec chciałabym przytoczyć indeks celów i wartości formułowanych przez respondentów. Jego interpretacja pozwala na odtworzenie zbiorowego horyzontu odpowiedzialności. W wypowiedziach opisywanej grupy znajdujemy następujące charakterystyki wartości/zadań/celów, którym służy/powinna służyć praca respondenta:

- praworządność;

- dobre, sprawne funkcjonowanie państwa;

- promowanie interesu ekonomicznego Polski;

- budowanie wizerunku Polski;

- reprezentowanie i obrona interesów Polski;

— kreowanie polskiej polityki zagranicznej i polityki bezpieczeństwa;

— sprawniejsze funkcjonowanie sądów;

- postęp cywilizacyjny, wyrównywanie poziomu cywilizacyjnego;

- ochrona zdrowia, troska o dobrostan społeczeństwa;

- obrona interesów grup społecznych;

- utrzymanie pokoju społecznego poprzez mądre współdziałanie z partnerami społecznymi;

- kreowanie dobrego wizerunku Polski.

Zarówno skrótowy indeks wartości (celów), jak i rozbudowane narracje dotyczące misji pełnionej przez respondentów świadczą o istnieniu dużych zasobów symbolicznych oraz umiejętności „zestawiania symboli”, czyli posługiwania się tymi zasobami w formułach autolegitymizacji. Dotyczy to zarówno obrazu codziennej odpowiedzialności, jak i „zaczarowanej” czy „odświętnej” misji. 


\section{UWAGI KOŃCOWE}

Co zatem, $\mathrm{w}$ świetle analizowanego materiału, można powiedzieć o tożsamości elity administracyjnej?

Relacja na linii polityka-biurokracja ma, jak można sądzić, stosunkowo skromny potencjał legitymizacyjny w odniesieniu do elit administracyjnych. Nasi respondenci nie sygnalizują, aby polityka w nadmierny sposób zagrażała ich autonomii. Są skłonni rozumieć autonomię jako indywidualną samodzielność i indywidualną odpowiedzialność Członkowie elity administracyjnej nie stanowią zintegrowanej, samoświadomej i konspirującej wobec elity politycznej grupy, lecz raczej zbiorowość autonomicznych jednostek. Ich autonomię, tak można sądzić, chronią prawo i kompetencje zawodowe.

Oprócz autonomii, dla tożsamości ważne jest poczucie odrębności, swoistości pełnionej roli i posiadanego statusu. Poczucie swej odrębności i wartości respondenci czerpią z własnej pracy, którą skłonni są opisywać jako misję.

Jednocześnie urzędnicy raczej nie budują poczucia własnej wartości na pokazywaniu swojej przewagi wobec polityków. Nie sygnalizują tym samym, aby we współczesnej Polsce doszło do „panowania urzędników”. Na teoretyczne pytanie: autonomia elity administracyjnej czy jej podporządkowanie polityce, odpowiedź brzmi: autonomia i podporządkowanie, a przede wszystkim współpraca, w zależności od konkretnej sytuacji i konkretnej decyzji.

Symboliczne zasoby legitymizacyjne wiążą się bardziej z indywidualnym poczuciem własnej wartości oraz tradycyjnej misji inteligenckiej niż z poczuciem przynależności do „wybranej grupy” elity administracyjnej ${ }^{13}$.

Waga powierzonych spraw, szeroki obszar wpływu i odczuwany „ciężar odpowiedzialności” czyni z dyrektorów departamentów zbiorowość o politycznej podmiotowości sprawczej. W typologii Jerzego Mikułowskiego Pomorskiego (2005) można ich przypisać zarówno do kategorii tych inteligentów, którzy „odwołują się do wartości inteligenckich”, jak i do kategorii „nowych profesjonalistów". Główne formuły legitymizacyjne opierają się na indywidualnych zasobach respondentów, na ich poczuciu powszedniej odpowiedzialności oraz poczuciu misji wyrażającej się w tworzeniu polityki, w służeniu państwu, służbie społecznej i osobistym poświęceniu.

Antoni Z. Kamiński (2014), a wcześniej w odniesieniu do Stanów Zjednoczonych Christopher Lasch (1997), dostrzegli i przekonująco opisali niebezpieczne zjawisko buntu czy dezercji elit, wyrażające się przede wszystkim $\mathrm{w}$ zrzeczeniu się odpowiedzialności za społeczeństwo i kierowaniu się w działalności interesem prywatnym bądź partykularnym. Takiej diagnozy nie potwierdziliby nasi respondenci. Ich dobre samopoczucie $\mathrm{w}$ dużym stopniu opiera się na deklarowanym (przyjmuję też, że odczuwanym) poczuciu odpo-

13 O spójności zbiorowości pośrednio może jednak świadczyć brak krytycyzmu wobec własnej grupy — w całej zbiorowości zaledwie jeden respondent krytykuje urzędników za pasywność. 
wiedzialności, zarówno odpowiedzialności przed, jak i odpowiedzialności za. I choć sami w gruncie rzeczy uprawiają politykę, można sądzić, że część „odpowiedzialności za" powierzają politykom. Jest to ważny czynnik poprawiający samopoczucie elit administracyjnych.

Nasze badania nie szły w kierunku wykrywania mechanizmów psychologicznych, które kryją się za analizowanymi narracjami. Mam tu na myśli dobrze udokumentowane we współczesnej psychologii społecznej mechanizmy rządzące autoprezentacją, obroną poczucia własnej wartości, mechanizmy racjonalizacji i redukcji dysonansów poznawczych. Samopoczucie członków elity jest związane z poczuciem wartości własnej. „Zapewne najsilniejszym motywem pozafizjologicznym - twierdzi Bogdan Wojciszke (2003, s. 22) — jest autowaloryzacja, dążenie do utrzymania, obrony i podwyższania dobrego mniemania o sobie”. W przyjętym przez nas podejściu wypowiedzi respondentów nie są przesiewane przez pryzmat wiedzy psychologicznej, ale przyjmowane „w dobrej wierze", warto jednak zaznaczyć, że ta obiegowa już niemal wiedza jest pomocna $\mathrm{w}$ rozumieniu analizowanego materiału empirycznego. Pomaga bowiem zrozumieć uderzająco dobre samopoczucie polskich elit administracyjnych.

\section{BIBLIOGRAFIA}

Ajnenkiel Andrzej, 1977, Administracja w Polsce. Zarys historyczny, Książka i Wiedza, Warszawa.

Betkiewicz Witold, 2014, Polski model kariery zawodowej urzędników wyższego szczebla? Próba empirycznego opisu, „Studia Polityczne”, nr 3 (35).

Etzioni-Halevy Eva, 1998, O autonomii elit $w$ demokracjach zachodnich, w: Jerzy Szczupaczyński (wyb. i oprac.), Wtadza i spoteczeństwo, cz. 2, Scholar, Warszawa.

Field G. Lowell, Higley John, Burton Michael G., 1990, A New Elite Framework for Political Sociology, „Revue Européenne des Science Sociales”, t. 28, s. 149-182.

Filipowicz Stanisław, 2002, Historia myśli polityczno-prawnej, Arche, Gdańsk.

Hausner Jerzy, 2008, Zarzadzanie publiczne, Scholar, Warszawa.

Heywood Andrew, 2006, Politologia, tłum. Barbara Maliszewska i in., Wydawnictwo Naukowe PWN, Warszawa.

Hodson Randy i in., 2013, Rules Don't Apply: Kafka's Insights on Bureaucracy, „Organization”, t. 20, nr 2.

Kamiński Antoni Z., 2014, Dezercja elit. Konsolidacja ustroju politycznego w pokomunistycznej Polsce, Instytut Studiów Politycznych PAN, Warszawa.

Krasnodębski Zdzisław, 1985, Maxa Webera projekt socjologii rozumiejacej, „Studia Socjologiczne”, nr 1.

Krasnodębski Zdzisław, 1998, Przedmowa. Weber po komunizmie, w: Max Weber, Polityka jako zawód i powołanie, tłum. Andrzej Kopacki, Paweł Dybel, Znak-Fundacja im. Stefana Batorego, Kraków-Warszawa.

Lasch Christopher, 1997, Bunt elit, tłum. Dobrosław Rodziewicz, Platan, Kraków.

Mach Bogdan, Mocek Stanisław, 2011, Rola wspótczesnej inteligencji w porządku demokratycznym, w: Irena Pańków (red.), Meandry legitymizacji, Instytut Studiów Politycznych PAN, Warszawa.

Mikułowski Pomorski Jerzy, 2005, Wprowadzenie, w: Jerzy Mikułowski Pomorski (red.), Inteligencja: między tradycją a wyzwaniami wspótczesności, Wydawnictwo Akademii Ekonomicznej, Kraków.

Nalewajko Ewa, Post Barbara, 2014, Dobre państwo i dobry urzędnik - krystalizacja wzorów normatywnych $w$ środowisku rządowych elit administracyjnych, „Studia Polityczne”, nr 3 (35). 
Obłój Krzysztof, 2001, Strategia organizacji, Polskie Wydawnictwo Ekonomiczne, Warszawa.

Oszlak Oscar, 2005, State Bureaucracy: Polities and Policies, w: Thomas Janoski i in. (red.), The Handbook of Political Sociology, Cambridge University Press, New York.

Pareto Vilfredo, 1994, Uczucia i działania. Fragmenty socjologiczne, tłum. różni, Wydawnictwo Naukowe PWN, Warszawa.

Pańków Irena, 2008, Elita polityczna $w$ teoriach i percepcji polskich parlamentarzystów, „Studia Polityczne", nr 20.

Peffley Mark, Rohrschneider Robert, 2007, Elite Beliefs and the Theory of Democratic Elitism, w: Russell J. Dalton, Hans-Dieter Klingeman (red.), The Oxford Book of Political Behavior, Oxford University Press, Oxford.

Peters B. Guy,1999, Administracja publiczna w systemie politycznym, tłum. Kazimierz W. Frieske, Scholar, Warszawa.

Picht Georg, 2011, Pojęcie odpowiedzialności, w: Krzysztof Michalski (red.), Zrozumieć przemijanie, Fundacja Augusta Hrabiego Cieszkowskiego, Warszawa.

Putnam Robert, 1993, The Political Attitudes of Senior Civil Servants in Western Europe: A Preliminary Report, „British Journal of Political Science”, t. 3, s. 257-290.

Raciborski Jacek, 2006, Wprowadzenie. Elity rzadowe jako przedmiot badań, w: Jacek Raciborski (red.), Elity rzadowe III RP 1997-2004. Portret socjologiczny, Trio, Warszawa.

Skotnicka-Illasiewicz Elżbieta, 2014, Administracja rządowa $i$ jej elity w warunkach członkostwa Polski w Unii Europejskiej, „Studia Polityczne”, nr 3 (35).

Świderski Bronisław, 2000, Konfrontacja „cienia” $z$ „panem”, „Plus Minus. Rzeczpospolita”, 7 października (głos w dyskusji Czy zmierzch inteligencji?).

Weber Max, 1998, Polityka jako zawód i powotanie, tłum. Andrzej Kopacki, Paweł Dybel, Znak-Fundacja im. Stefana Batorego, Kraków-Warszawa.

Wesołowski Włodzimierz, 1992, Parlamentarzyści jako część elity politycznej: teoretyczno-porównawcze tło polskich badań, w: Jacek Wasilewski, Włodzimierz Wesołowski (red.), Poczatki parlamentarnej elity. Postowie kontraktowego Sejmu, IFiS PAN, Warszawa.

Wojciszke Bogdan, 2003, Cztowiek wśród ludzi. Zarys psychologii spotecznej, Scholar, Warszawa.

Wołek Artur, 2012, Stabe państwo, Ośrodek Myśli Politycznej-ISP PAN, Kraków-Warszawa.

Znamierowski Czesław, 1991, Elita i demokracja, Instytut Wydawniczy Pax, Warszawa.

Zybała Andrzej, 2012, Polityki publiczne. Doświadczenia w tworzeniu i wykonywaniu programów publicznych $w$ Polsce $i$ w innych krajach. Jak działa państwo, gdy zamierza/chce/musi rozwiąać zbiorowe problemy swoich obywateli?, Krajowa Szkoła Administracji Publicznej, Warszawa.

Żyro Tomasz, 2006, Wstęp do politologii, Wydawnictwo Naukowe PWN, Warszawa.

\section{ADMINISTRATIVE ELITES: MISSION AND RESPONSIBILITY}

\section{Sum mary}

This article contains the results of research and analyses concerning the administrative elite forming in contemporary Poland. Particular attention is paid to relations between politics and the administration and between civil servants and politicians, as well as to the manner in which the administrative elite perceive their tasks and responsibilities. The article is based on in-depth interviews conducted in 2013 with 50 department directors and vice directors in Polish ministries.

\section{Key words/słowa kluczowe}

administrative elite / elita administracyjna; relation between politics and administration/ relacja polityka-administracja; mission / misja; responsibility / odpowiedzialność 